activity of the GSH-Px of all treated kids of untreated and treated dams was $177,245,240$, 150 and $143 \mathrm{U} / \mathrm{g}$ respectively for Hemoglobin $(\mathrm{Hb})$. The comparable values of the untreated kids of untreated and treated dams were $39,55,91,68$ and $78 \mathrm{U} / \mathrm{g}$ respectively for $\mathrm{Hb}$. The observed difference was significant $(\mathrm{P}<5 \mathrm{p} .100)$.

Compared to the dam treatment, the kid treatment seems to have a stronger influence both on the Se- and vitamin E supply.

When selenium was administered to the kids orally one day after birth in the form of drenches (same time and same quantity as by injection), a slightly lower effect ( $P>5$ p. 100) was observed as shown by the GSH-Px activity. From the first to the fourth week of life this activity up from $18 \mathrm{U} / \mathrm{g}$ to $91 \mathrm{U} / \mathrm{g} \mathrm{Hb}$ in the injection group. When selenium was administered in the form of drenches, the corresponding values were $22 \mathrm{U} / \mathrm{g}$ and $84 \mathrm{U} / \mathrm{g} \mathrm{Hb}$, resp.

Key words : Selenium, vitamin E, goat, kid, supplementation, parenteral, oral.

\title{
The use of milk replacers based on soya protein and whey for kid
}

\author{
A. MOWLEM \\ Animal and Grassland Research Institute, Shinfield, Reading, RG2 9AQ, England
}

A wide range of milk replacers are available for rearing calves and few specifically for goat kids. The performance, in terms of growth rate, was recorded for two groups of goat kids reared on two commercially available milk replacers based on skim milk and on soya protein and whey. This was offered via a multi-teat self feeder and the kids were weaned at 6 weeks.

The two milk substitutes used were Denkwik made up from a minimum of 62 p. 100 skim milk with tallow and coconut oil to give an analysis of 16 p. 100 fat and 26 p. 100 crude protein and Speen-Foc made up from 10 p. 100 alcohol treated soya protein with whey, whey protein concentrate, tallow and coconut oil. Both were manufactured by British Denkavit, Poole, England. From 2 weeks of age the kids had ad libitum access to grass hay, a calf weaner pencil (16 p. $100 \mathrm{CP}$ BOCM, Basingstoke, England) and clean water.

A difference in growth rate $(P<0.05)$ in favour of the soya-whey replacer group was recorded. Between weeks 1-10 the soya-whey group gained $14.4 \mathrm{~kg}$ compared with $12.6 \mathrm{~kg}$ for the skim milk replacer group. No evidence of allergenicity of soya protein was seen, the only cases of diarthoea recorded were directly attributable to coccidiosis where some animals from each group were affected. Later comparison at +18 weeks of age showed no significant difference and it was concluded that for early weaning, at least, the choice of milk replacer is not so important in terms of growth performance and it is likely that economic factors will therefore influence the choice of feed. At the time of writing the UK price for the skim based product is $£ 770$ /tonne, the soya-whey product $£ 650$ /tonne and goat milk in terms of dry matter has a wholesale value of $£ 3000$ /tonne. When related to cost of rearing a kid to a weaning age of 6 weeks, this would require $£ 8.5$ of skim milk replacer, $£ 7$ for the soya-whey product or $£ 27$ for an equivalent quantity of goat milk.

Key words : Goat, milk-replacer, soya protein, rearing, whey. 